\title{
乳牛の肝藏機能診断に関する研究
}

\section{一般および簡易尿検查所見による 肝臓機能異常の診断}

\author{
星野邦夫 ${ }^{* 1}$. 鈴木慶信 ${ }^{* 2}$. 香本頴利 ${ }^{* 2} \cdot$ 大脇雄三 ${ }^{* 2}$ \\ (1981年 8 月 1 日 受理)
}

\begin{abstract}
要 約
数量化理論 2 類の方法を応用して, 乳牛の一般臨床所見およU゙簡易臨床検查所見から, 肝䑏機能が異常な乳 牛を診断しようとする研究を行った。

検討1では, 51頭のホルスタイン乳牛を用いた。

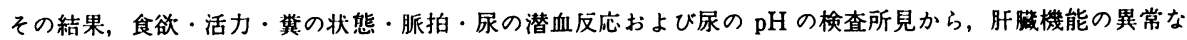
牛を診断するための判別方程式を求めることができた。

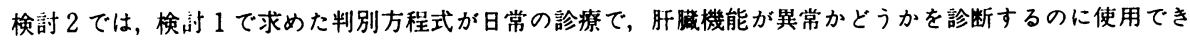
るかどうかをしらべた。

その結果, BSP (フロムサルファレイン) の排泄能検査によって, 肝嘰機能が異常と診断した11頭のうち 9 頭が, 判別方程式によっても、肝嘰機能が巽常と診断された。しかし，BSP排泄能検查によって，軽度の肝脸 機能低下と診断した 6 頭のうち 5 頭が, 判別方程式による診断では肝荿機能異常牛と誤診された。肝哓機能が 正常な乳牛で, 異常と診断されたものはなかった。

この研究の結論として, 軽度の肝脿機能低下牛を軽度の異常牛と考えれば, 検討 1 で求めた判別方程式は, 野外での肝臓機能異常牛のスクリーニング用として応用できると考える。
\end{abstract}

牛の肝臟機能の異常は, 一般臨床症状から診断す ることは困難である。従って,一般臨床症状のほか に, 肝藏機能診断に必要とされている血液・尿成分 などを検查し，これらの所見を検討することによっ て診断が行われている。しかし，多くの所見は，肝 臓以外の異常でも変動しているし，確実な診断を期 して多種の検查を行っても，個体によってそれぞれ の所見が相違するため, 実際には, 肝葴機能の診断 は容易でない。このことから，著者らは，より確信 のもてる実用的な診断法を求めて研究を行なってき た ${ }^{3,6)}$ 。

今回は, 数量化理論 II 類の方法 ${ }^{2)}$ を応用し, 一般 および簡易臨床検查所見を，肝臓機能の総合判別得 点というかたちで，客観的に要約する判別方程式を 求めることができれば，この式を利用して，患畜の かたわらでの肝臟機能の診断が可能になる，との仮 定のもとに研究を行なった。

*1 束京農工大学農学部

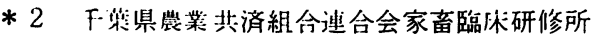

\section{研究方法（材料と方法）}

1. 判別方程式を求めるための材料と方法 材料：1980年 7 月から11月の間に,千葉県農共連 家畜臨床研修所管内に飼育され，産後疾病あるいは 繁殖障害等で診療経過中のホルスタイン乳牛51頭に ついて調べた一般臨床所見, 簡易尿検查所見（以上 表 1 参照) および肝臓のブロムサルファレイン（以 下BSP と略す）排泄能所見のデータである。

方法：ます， BSP 停滞の程度により，供試牛 51 頭を 3 グループに分類した。すなわち， BS P 注射 後30分にBSP 停滞のなかったものを肝臓機能正常 牛グループ(8 頭)，30分後 3〜9\%停滞していたも のを肝臓機能軽度低下牛グループ(20頭), 30 分後 10 \%以上停滞していたものを肝臓機能異常牛グループ （23頭）に分類した。そして，これらを外的基準と した。各個体の一般および簡易尿検査所見デー夕は, 内的基準とし，数量化理論 II 類のモデルを用いて判 別分析を行い, 判別方程式の係数, 偏相関係数およ び相関比を求めた。これらの計算は, 東京大学大型 計算機センターの HITAC M-200H システムを利 用し, PPSS II Quant 2 のプログラムによって行 
なった。

なお，BSP 排泄能検査は，5\%ブロムサルファ レイン注射液（第 1 製薬）を用い，所定の方法 ${ }^{1)} に$ よって実施し，判定は大脇ら ${ }^{3)}$ の方法によった。簡 易尿検査には $\mathrm{BM}-6$ (中外製薬) を用いた。また， 内的基準に用いた検査項目（表 1 参照）は，一連の 研究のためにとりあげた全19項目について, 数量化 理論 II 類による分析をくり返し，相関比および偏相 関係数の大きさを勘案しながら選出（過程は省略） した。

2. 判別方程式の実用性検討のための材料と方法 材料：1980年11月から 1981年 7 月までの間に, 同 じ家畜臨床研修所管内で，新たに診療した22頭のホ ルスタイン乳牛の食欲・活力・翼の状態・脈拍数 · 尿潜血反応およびBSP 排泄能を調べた。

方法：新たな個体の上記のデータを，1の方法で 求めた判別方程式に代入して各個体の判別得点を計 算し，22頭の肝臓機能を判定した。次いで，この判 定結果が，それぞれの個体のBSP排泄能検查によ る診断結果と一致するかどうかを調べた。

なお，データの採取は， 1 と全く同じ方法で行な つた。

\section{成}

表 1 に，分析に用いた検査項目，検查所見および 分析結果を示した。基準化判別係数は，判別方程式 (表の最下欄) の係数であり，診断しようとする乳 牛の判別得点 $Y$ は，その個体の各検査所見 $X_{j}^{(i)}$

（1または 0 ）を，判別方程式に代入して求める。

各検査項目が診断に奇与する程度は, 偏相関係数 の大・小で示されるため, 今回とりあげた検査項目 が肝臓機能診断に寄与する順は, 偏相関係数の大き さの順, すなわち食欲・尿 $\mathrm{pH} \cdot$ 尿潜血反応・活力・ 糞の状態・脈拍数の順であった。判別方程式の判別 力の指標である相関比は 0.841 であった。

表 2 に,グループ別に, 对象牛51頭の判別得点を 示した。肝臓機能正常牛および軽度低下牛の得点は すべて正であり, これに対し, 肝蔵機能異常牛の得 点は, 23頭中21頭が負で, 他の 2 グループとよく分 離した。

表 2 の結果を見やすくして図1に示した。BSP 排泄能検查で肝臓機能異常牛と診断した23頭のうち 22頭が, 判別方程式によっても，他の 2 グループと は明らかに異る位置（判別点30.7以下）に判別され ている。肝臓機能軽度低下牛と正常牛は, 判別点
211.0 でおおむね判別されているが, 正常牛の位置 にある11頭のうち 5 頭が軽度低下牛であり, 誤判別 が多い。

なお, 判別点は次の式 ${ }^{2)}$ によって求めた。

$$
\begin{aligned}
& Z_{c}=\frac{x_{1} s_{2}+x_{2} s_{1}}{s_{1}+s_{2}} \\
& x_{1}, x_{2}, s_{1}, s_{2} \text { は, それぞれのグループ } \\
& \text { の判別得点の平均值および標準偏差 }
\end{aligned}
$$

\begin{tabular}{|c|c|c|c|}
\hline 検 查項 目 & 検査所見 & 基準化判別係数 & 偏相関 \\
\hline$X^{(i)}$ & $X_{j}^{(i)}$ & $\beta_{j}^{(i)}$ & 係 数 \\
\hline 欲 $X^{(1)}$ & $\begin{array}{l}0 \sim 20 \% \text { 古 } \\
30 \sim 40 " \\
50 \sim 60 " \\
70 \sim 80 " \\
90 \sim 100 "\end{array}$ & $\begin{array}{r}-258.1 \\
-138.1 \\
-103.2 \\
188.5 \\
262.5\end{array}$ & 0.75 \\
\hline 力 $X^{(2)}$ & $\begin{array}{l}0 \sim 20 \% \frac{1}{i} \\
30 \sim 40 " \\
50 \sim 60 " \\
70 \sim 80 " \\
90 \sim 100 "\end{array}$ & $\begin{array}{r}-30.5 \\
124.3 \\
103.3 \\
13.4 \\
-142.2\end{array}$ & 0.51 \\
\hline 蕒の状態 $X^{(3)}$ & $\begin{array}{c}\text { 下痢・軟便 } \\
\text { 普 通 } \\
\text { 硬 便 }\end{array}$ & $\begin{array}{r}-92.5 \\
40.9 \\
-61.0\end{array}$ & 0.43 \\
\hline 拍 $X^{(4)}$ & $\begin{array}{c}100 \text { 回/分以上 } \\
90 " \text { 台 } \\
80 " \text { " } \\
70 " ~ \\
60 " ~\end{array}$ & $\begin{array}{r}-21.5 \\
9.6 \\
-\quad 3.0 \\
-\quad 38.9 \\
79.9\end{array}$ & 0.31 \\
\hline 尿 潜 血 $X^{(5)}$ & $\begin{array}{l}250 \mathrm{Ery} / \mu l \\
50 " \prime \\
5 \sim 10 " \\
\text { neg. }\end{array}$ & $\begin{array}{r}-237.2 \\
51.2 \\
-137.4 \\
22.0\end{array}$ & 0.56 \\
\hline 尿 $\mathrm{pH} \quad X^{(6)}$ & $\begin{array}{l}5> \\
6 \\
7 \\
8 \\
9< \\
\end{array}$ & $\begin{array}{r}361.4 \\
-121.3 \\
-141.8 \\
24.4 \\
50.4 \\
\end{array}$ & 0.66 \\
\hline 判別方程式 & \multicolumn{3}{|c|}{$\begin{array}{l}Y=\sum_{i=1}^{6} \beta_{j}^{(i)} X_{j}^{(i)} \\
X_{j}^{(i)} \text { は, 検査所見に該当のとき } 1, \\
\text { 該当しないとき } 0 \\
i=1,2,4,6 の と き ~ \\
i=3 \text { のとき } \quad j=1,2, \cdots, 5 \\
i=5 \text { のとき } \quad j=1,2,3,4 \\
i=1,3\end{array}$} \\
\hline
\end{tabular}

図 2 に, 求めた判別方程式による新たな22頭の乳

表 1 分析に用いた検査所見および分析結果

注 : 相関比 : $\eta^{2}=0.841$ 
表 2 BSP 排泄能検查でグループ分けした個体の判別得点

\begin{tabular}{|c|c|c|c|c|c|}
\hline \multicolumn{2}{|c|}{ 正常牛グループ } & \multicolumn{2}{|c|}{ 軽度低下牛グループ } & \multicolumn{2}{|c|}{ 異常牛グループ } \\
\hline 個体No. & 判別得点 & 個体No. & 判別得点 & 個体№. & 判別得点 \\
\hline 1 & 243.2 & 9 & 167.3 & 29 & -248.5 \\
\hline 2 & 230.7 & 10 & 194.8 & 30 & -338.4 \\
\hline 3 & 243.3 & 11 & 287.6 & 31 & -472.7 \\
\hline 4 & 323.9 & 12 & 19.6 & 32 & -255.4 \\
\hline 5 & 225.9 & 13 & 193.4 & 33 & 19.5 \\
\hline 6 & 126.2 & 14 & 194.8 & 34 & -316.1 \\
\hline 7 & 204.6 & 15 & 168.7 & 35 & -184.5 \\
\hline \multirow[t]{16}{*}{8} & 311.3 & 16 & 86.8 & 36 & $-299 . \bar{i}$ \\
\hline & & 17 & 152.2 & 37 & -318.1 \\
\hline & & 18 & 157.7 & 38 & -196.7 \\
\hline & & 19 & 287.6 & 39 & -88.5 \\
\hline & & 20 & 243.3 & 40 & -83.6 \\
\hline & & 21 & 243.3 & 41 & -338.6 \\
\hline & & 22 & 156.7 & 42 & -227.4 \\
\hline & & 23 & 132.4 & 43 & 71.2 \\
\hline & & 24 & 71.2 & 44 & -268.0 \\
\hline & & 25 & 194.8 & 45 & -201.5 \\
\hline & & 26 & 267.5 & 46 & -238.1 \\
\hline & & 27 & 194.8 & 47 & -316.1 \\
\hline & & 28 & 194.8 & 48 & -375.9 \\
\hline & & & & 49 & -280.5 \\
\hline & & & & 50 & -333.1 \\
\hline & & & & 51 & -228.4 \\
\hline $\bar{x}$ & 238.7 & & 180.5 & & -239.9 \\
\hline$s$ & 57.7 & & 67.3 & & 122.1 \\
\hline
\end{tabular}

注: 对象牛 51 頭

牛の肝臓機能診断結果を示した。

判別方程式の実用にあたっては，できる限り誤診 を避けなければならないので, 次のような判定領域 を設けた。すなわち，図1に示してあるグループご との分布（判別得点による）について，1\%水準の 棄却限界を計算し, 肝臓機能異常牛グループの上方 （右限）棄却限界 119.4 と軽度低下牛グループの下 方 (左限) 棄却限界-23.3の区間の判別得点の個体 は，無理に判定しない立場をとり，この区間を診断 保留域とした。また, 判別得点一23.3以下は肝臟機 能異常牛と診断する領域, 判別得点 119.4 以上は(図 1 から判断して）肝臓機能軽度低下牛又は正常牛と 診断する領域とし，図 2 に記載した。判定はこれに 従って行った。

裹却限界の計算は次の式4)によった。

$$
\bar{x}+s \sqrt{\frac{n+1}{n} F_{0}} \geqq \bar{x}-s \sqrt{\frac{n+1}{n} F_{0}}
$$

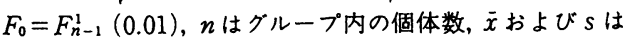
そのグループの判別得点の平均值および標準偏差
図2の結果を説明すると，BSP 排泄能検査で肝 臟機能が異常と診断した11頭のうち 9 頭が, 判別方 程式によっても，肝臓機能異常牛と診断する領域に 判別された。しかし，BSP 排泄能検査で軽度の肝

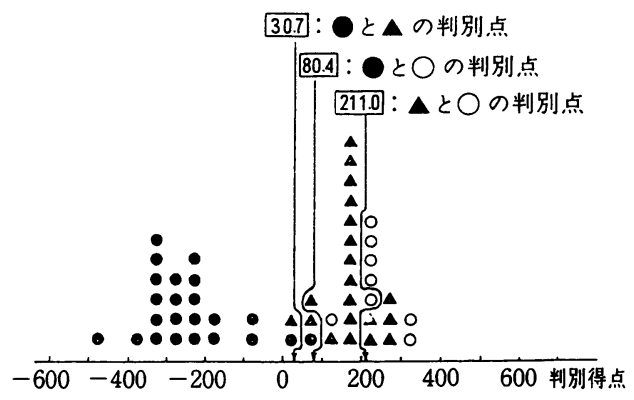

図 1 一般および簡易臨床検査所見による判別

（表 2 を図示したもの）

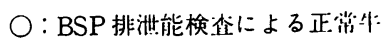

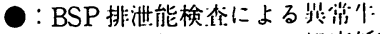

$\Delta$ ：BSP 排洲能検企による軽没低下゙ 


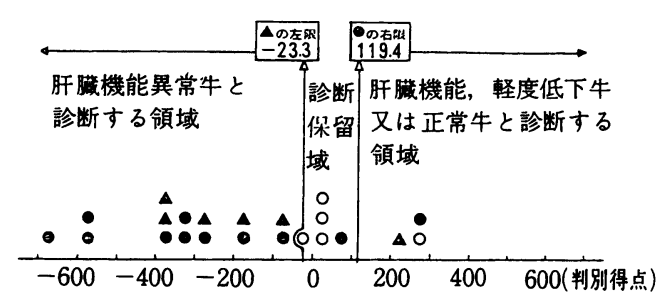

図 2 判別方程式による実際の肝䑏機能診断

$\bigcirc: \mathrm{BSP}$ 排泄能検査でも正常牛

: BSP 排泄能検査でも異常牛

$\Delta$ : BSP 排泄能検査でも軽度低下牛

臓機能低下牛と診断した 6 頭のうち 5 頭もが, 判別 方程式による診断で肝臓機能異常牛と診断する領域 に判別され, 誤診であった。BSP 排泄能検查正常 牛で, 異常牛領域に判別されたものはなかった。119.4 以上の軽度の肝臓機能低下牛又は正常牛の領域には, BSP 検查異常牛 1 頭が誤判別された。なお, 診断 保留域には, BSP 検查による正常牛 4 頭, 異常牛 1 頭が入った。

\section{考察およびまとめ}

人の臨床診断面においては, 早くから多くの臨床 的情報を客観的に要約し診断する, 計量診断法が開 発されている5)。しかし，家畜疾病の臨床診断面に おいては、これらがいまだ開発されていない。

確実な臨床診断のためには, 利用する臨床的情報 は多いほど有利であると当然考えられる。しかし， 実際には，診断に利用する多くの情報，すなわち窅 告，一般所見および臨床病理検査所見は，同一疾病 であっても個体によって相違するものが多く，かえ つて診断をまよわせてしまう。この問題を解決する には，各個体の示す所見の微妙なばらつきを，客観 的に整理総合化する方法を見いださなければならな い。これらの方法を模索するため，著者らは，現在 も生前の診断が困難視されている肝臓機能診断にと りくみ，一連の研究を行っている。今回は，その 一環として, 数量化理論II類の方法を応用し, 肝機 能異常牛を診断するための研究を行った。

まず，ホルスタイン乳牛51頭の一般臨床所見，簡 易尿検查所見および肝臓の BSP 排泄能所見のデー 夕をもとに，判別分析を行った。その結果，高い 相関比をもつ肝蔵機能診断のための判別方程式を得 ることができた。次に，分析に用いた同じ51頭のデ 一夕を判別方程式に代入し，判別得点を求め判別方
程式の診断力を調べた。その結果では，BSP 排泄 能検查で肝㖑機能異常牛と診断したものの $95.6 \%$ が, 判別方程式でも異常牛と診断され，この判別方程式 が肝臟機能異常牛の診断に，かなり役立つことが示 唆された。しかし, 肝臓機能の軽度低下牛おょび正 常牛の判別は不十分であった。従って，之られた判 別方程式は, 肝臓機能異常牛の診断には応用可能で あるが, 肝臟機能軽度低下牛と正常牛の判別には, 応用できないと考えられた。

そこで，この判別方程式が，日常の診断に使用で きるかどうか，新たな疾病治療牛について，実際に 診断を行なってみた。その結果の中で，BSP 排泄 能検査で肝臓機能異常牛と診断した11頭のうち 9 頭 が，判別方程式によっても異常牛と診断され，約 82 \%の適中率を示した。しかし，BSP 排泄能検查に よる軽度の肝臓機能低下牛 6 頭についての判別方程 式の診断結果は， 5 頭までが異常牛に誤診されここ の判別方程式の一般性の弱さが明らかとなった。こ のことは, 判別方程式を求めるためのデータが51頭 のものにすぎず不足であったこと，BSP 停滞率は 連続量であるため，外的基準とした各グループを分 類するための切点にあいまいさが存在したこと，実 際には肝藏機能正常牛が少なく，データがえられず 不足のまま分析を行ったことなどが関与した結果起 つた問題であると考えられる。今後は、これらの 問題をふま之，例数をふやし分析をやク直すなどし て，一般性の高い判別係数を求める必要があると考 える。

しかしながら, 肝臟機能正常牛で異常牛と診断さ れたものがないことを考虑し, 軽度の肝臟機能低下 牛を軽度の異常牛として扱う立場をとれば，今回え られた判別方程式は，患畜のかたわらでの肝臟機能 異常牛のスクリーニング用として応用できるものと 考之る。なお，無理に診断しない保留域に入ったも のが 5 頭あったが, これらについては，その他の検 查を追加するなりして，別途に診断すべきであろう。

\section{引用交献}

1）飯塚三喜：家苗衛生に必要な臨床生化学的検査 法(農林水産省家畜衛生試験場共同監修)。日本獣 医師会, 173 188, 曺吕 1975 .

2）林知已夫, 樋口伊佐矢, 駒沢勉 : 情報処理と統 計数理. 223 304, 産業図書, 東京, 1976.

3）大脇雄三ら：乳牛の肝臓機能診断に関する研究. 異物排泄能試験の応用. 家亩診療, 214, 16 22, 
1981.

4）鳥居敏雄, 高橋映正, 土肥一郎：医学生物学の

ための推計学. 1 44, 東大出版会, 東京, 1966.

5）高橋映正，宮原英夫：臨床診断とコンピュータ．
$1 \sim 151 ， 275 \sim 293$, 産業図書, 東京, 1972.

6）上原喜久司ら：乳牛の肝臓機能診断に関する研 究. 1. 各種検查所見による肝臓脂肪化の計量診断. 家苗診療, 212, 11 - 17, 1981.

\title{
Studies on the Diagnosis of Liver Conditions in Dairy Cows with Special Reference to the Diagnosis of Hepatic Dysfunction on the Basis of General Symptoms and Results of Simplified Urinalysis
}

\author{
Kunio Hoshino \\ Tokyo University of Agriculture and Technology, Saiwai-cho \\ Fuchu-shi, Tokyo 183 \\ Yoshinobu SuzUKI, Hidemichi Komoto and Yuzo ŌWAKI \\ Veterimary Training Center of Chiba Agricultural Insurance \\ Association, Sueyoshi, Kimitsu-shi, Chiba 292-03
}

(Received August 1, 1981)

\section{Summary}

By the application of quantification model No. 2 an attempt was performed to make a diagnosis of functional disorders of the liver in dairy cows on the basis of general symptoms and the results of simple laboratory examination.

Trial 1 was carried out on 51 Holstein cows. As a result, it was possible to obtain a discriminant function for the diagnosis of functional disorders of the liver in cows on the basis of appetite, energy, consistency and form of feces, pulse, occult blood, reaction, hemoglobinuria and hematuria, and results of examination on the $\mathrm{pH}$ of urine.

Trial 2 was conducted to determine whether the discriminant function obtained in the preceding trial was available for the diagnosis of hepatic dysfunction in the everydail practice of buiatrics or not. As a result, a positive diagnosis of hepatic dysfunction was made successfully by the application of this function in nine of eleven cows in which the bromsulphalein test hac revealed the same hepatic dysfunction. On the other hand, when a diagnosis of slight depression of the function of the liver was made in six cows by the bromsulphalein test, an erroneous diagnosis of abnormality in the function of the liver was made in five of these cows by the application of the discriminant function obtained in trial 1 and used for diagnosis. It was not made, however, in any dairy cow with a normal hepatic function.

It was concluded from these studies that the discriminant function obtained in trial 1 was applicable to a screening test of cattle affected with abnormality in the function of the liver in the field, on condition that cattle with slight depression of the function of the liver were regarded as those with mild abnormality in the function of this organ. 